\author{
Таїсія Ткачук, \\ доктор психологічних наук, \\ професор, завідувач кафедри \\ практичної психологіі \\ ДВНЗ «Переяслав-Хмельницький \\ державний педагогічний \\ університет імені Григорія \\ Сковороди»
}

E-mail: taisiya07@ukr.net

ORCID 0000-0002-2721-6392

Ангеліна Мягких, студентка педагогічного факультету ДВНЗ «ПереяславХмельницький державний педагогічний університет імені Григорія Сковороди»

\author{
Taisiia Tkachuk, \\ Doctor of Psychology, \\ Professor, Head of the Applied \\ Psychology Department \\ of the SHEI «Pereiaslav-Khmelnytskyi \\ Hryhorii Skovoroda \\ State Pedagogical University»
}

E-mail: linakin96@gmail.com

ORCID 0000-0003-2318-0860

\title{
ГЕНДЕРНІ ОСОБЛИВОСТІ КОПІНГ-ПОВЕДІНКИ ЧОЛОВІКІВ ТА ЖІНОК
}

У статті проаналізовано феномен копінгу в сучасній психологічній науці. Відзначено, щзо «копінг» або «копінг-поведінка», які вважаються синонімами, здійснюється на основі копінгресурсів за допомогою копінг-стратегій. Наведено результати власного емпіричного дослідження частоти вибору стратегій подолання стресу чоловіками і жінками. Зазначено, щяо при вивченні відмінностей у виборі шляхів подолання стресу чоловіками $і$ жінками необхідно враховувати як біологічні, так $і$ сочіокультурні чинники, а вибір індивідом певних стратегій подолання є досить стабільною характеристикою протягом усього життя, незалежно від типу стресора. Проаналізовано три основні стратегії копінгу: розв'язання проблем, пошук соиіальної підтримки та уникання проблем. Підкреслено, щзо жінки орієнтовані не стільки на психологічне подолання складної життєвої ситуації, скільки на адаптацію до неї; стратегї подолання чоловіків базуються на незалежних і активних діях, емочійній стійкості та самоефективності, які характеризують інструментальні стратегї, щчо спрямовані на розв'язання проблем. Виявлено, щуо проблемно-орієнтоване подолання негативно корелює з жіночим типом гендерної ідентичності, втім фемінні жінки частіше характеризуються вибором емочійно-орієнтованих стратегій та копінгом, орієнтованим на уникання проблем, однією з сторін якого є тенденція до соиіальної підтримки; представники чоловічого та андрогінного типів гендерної ідентичності віддають перевагу стратегіям розв'язання проблем. Зроблено висновок, що стратегія подолання "вирішення проблем" є домінуючою у більшості досліджених чоловіків, які в стресових ситуаціях намагаються використати всі наявні особисті ресурси для пошуку можливих шляхів ефективного вирішення проблеми; жінки, навпаки, у разі виникнення важких життєвих ситуацій прагнуть знайти емоційну та інструментальну підтримку у своєму безпосередньому сочіальному середовищі, що характеризує стратегію вирішення проблеми «пошук соціальної підтримки».

Ключові слова: стрес, копінг, копінг-поведінка, копінг-ресурси, копінг-стратегії, гендерні особливості, емоиійно-орієнтований копінг, проблемно- орієнтований копінг, фемінний 


\section{Psychology}

тип гендерної ідентичності, маскулинний тип гендерної ідентичності, андрогінний тип гендерної ідентичності.

The article analyzes the phenomenon of coping in modern psychological science. It is noted that coping or "coping-behavior», which are considered as synonymous, is carried out on the basis of coping-resources with the help of coping strategies. The results of their own empirical study of the frequency of choosing coping strategies by men and women are presented. It is noted that in studying the differences in the choice of ways to overcome stress between women and men, it is necessary to consider both biological and socio-cultural factors. It is noted that the choice of an individual of certain coping strategies is a rather stable characteristic throughout life, independent of the type of stressor. Typically, 3 basic copying strategies are identified: problem solving, social support search, problem avoidance. It is emphasized that women are oriented not so much on the psychological overcoming of a difficult life situation, but on adapting to it. Men's coping strategies are based on independent and active actions, emotional sustainability and self-efficacy, which characterize problem-focused strategies to overcome difficulties. It is analyzed that problem-oriented coping negatively correlates with the feminine type of gender identity. However, feminine women are more likely to be characterized by emotional-oriented coping, and especially coping, focused on avoiding the problem, one of the parties which has a tendency to seek social support. Representatives of masculine and androgynous types of gender identity prefer to overcome the problem-solving. It is noted that the coping strategy of «problem solving» has appeared to be dominant in the majority of investigated men who in stressful situations try to use all available personal resources for them to find possible ways of effective solution of the problem. Instead, women in case of difficult life situations seek to find emotional and instrumental support in their immediate social environment, which characterizes one of the basic coping strategies «search for social support».

Keywords: stress, coping, coping-behavior, coping-resources, coping strategies, gender features, emotional-oriented coping, problem-oriented coping, feminine gender identity, masculine type of gender identity, androgenic type of gender identity.

Постановка проблеми. Проблема дослідження гендерних особливостей подолання стресу нині остаточно не досліджена. Індивідуальні відмінності і діапазон можливих стресорів $є$ настільки великим, що достатньо грубий поділ за статевою ознакою не завжди $\epsilon$ правомірним. Нині не існує переконливих доказів, які свідчили б, хто краще - чоловіки чи жінки - долають стрес. Більшість дослідників висувають універсальні «безстатеві» моделі людини, що не враховують особливості мислення, поведінки і особистісних якостей чоловіків та жінок. На сьогодні необхідне вивчення особливостей реагування i поведінки в стресовій ситуації представників різних статей, тобто врахування їхніх гендерних особливостей.

Аналіз останніх досліджень та публікацій. Поняття «соріng» у перекладі з англійської мови означає опановувати, долати (від англ. to cope). Процеси, спрямовані на подолання стресових станів прийнято називати копінгом або копінг-поведінкою. Також дуже часто у понятті копінг-поведінки вживається термін «психологічне подолання» як індивідуальний спосіб взаємодії з важкою ситуацією (зовнішньою або внутрішньою), який визначається її суб `ктивною значущістю для людини 3 одного боку, і ії власними психологічними можливостями - 3 іншого. Втім поняття «копінг-поведінка» може позначати досить широкий спектр 
активності людини - від психологічних захистів до цілеспрямованого подолання кризових ситуацій.

Копінг-поведінка здійснюється на основі копінг-ресурсів за допомогою копінг-стратегій. До останніх належать базові копінг-стратегії розв'язання проблеми, пошук соціальної підтримки і уникнення.

Дана галузь досліджень склалася досить недавно, на початку 60-х pp. ХX століття. Вивчення копінгу бере свій початок від робіт Л. Мерфі, який досліджував способи подолання дітьми вікових криз [Murphy, 1962]. Автор когнітивної теорії стресу Р. Лазарус вважав, що між чоловіками і жінками відсутні усталені розбіжності у виборі копінгстратегій. Утім у багатьох наукових працях 3 проблем подолання зазначається, що на вибір копінг-стратегії в складній життєвій ситуації впливають статево-рольові стереотипи, а саме жінки (і фемінні чоловіки) схильні до емоційної реакції на проблему, а чоловіки (і маскулинні жінки) вибирають «інструментальні» методи шляхом зміни зовнішньої ситуації. Також підкреслюється схильність чоловіків до проблемно-орієнтованого копінгу.

Нині немає єдиної точки зору щодо наявності гендерних особливостей подолання складних життєвих ситуацій. Це означає, що в науковій літературі залишається ще недостатньо з'ясованим, як проявляються гендерні відмінності копінгу в певних стресових ситуаціях.

Метюю даної статті є дослідження гендерних особливостей копінгповедінки чоловіків та жінок.

Виклад основного матеріалу дослідження. У рамках проблеми гендерних особливостей у виборі копінг-стратегій проводилися різні дослідження. Вивчаючи відмінності у виборі способів подолання стресу між жінками i чоловіками, необхідно враховувати i біологічні, i соціокультурні чинники. 3 точки зору теорії еволюції жінкам більш властиво пристосовуватися до важкої ситуації, оскільки фемінність характеризується високою пластичністю (адаптивність). Чоловіки ж виходять із ситуації, прагнучи знайти нове рішення, труднощі лише стимулюють їхній пошук. Їм більшою мірою властиві такі якості, як спритність, кмітливість, винахідливість, що забезпечують останнім виживання у важких умовах. Слідуючи за природними особливостями жіночої та чоловічої сутності, більшість культур у свою чергу приписує і заохочує такі особливості поведінки дівчинки (майбутньої жінки), як пасивність, концентрація на почуттях, прояв емоцій і прагнення розділити їх $з$ іншими; і особливості поведінки хлопчика (майбутнього чоловіка) прагнення бути активним, неемоційним, не проявляти слабкість. Під впливом культури природна сутність жіночої статі трансформується в жіночі риси характеру в той час, як чоловічі риси характеру грунтуються на природній сутності чоловічої статі [Москвитина, 2002].

С. Фолкман і Р. Лазарус визначили 8 видів ситуативно-специфічних копінг-стратегій: планомірне вирішення проблем, позитивна переоцінка, 


\section{Psychology}

прийняття відповідальності, пошук соціальної підтримки, конфронтація, самоконтроль, дистанціювання, уникнення [Lazarus, Folkman, 1987].

Дж. Амірхан вважав, що вибір індивідом тих чи інших копінгстратегій є достатньо стабільною характеристикою протягом усього життя, малозалежною від типу стресора. Він позначив їх як базисні стратегії поведінки людини і об'єднав у три групи: 1) вирішення проблеми (адаптивна); 2) пошук соціальної підтримки (адаптивна); 3) уникнення проблеми (неадаптивна) [Amirkhan, 1990].

Незважаючи на те, що ці фундаментальні стратегії не вичерпують усіх копінг-можливостей особистості, автор підкреслює, що вони відповідають основним людським реакціям на загрозу, характеризуючи тим самим загальні тенденції копінг-поведінки. Науковець Л. Собчик також вважає, що тип реагування в стресових ситуаціях є «продовженням провідної індивідуально-особистісної тенденції», що базується на типі вищої нервової діяльності, $€$ вродженою, генетично обумовленою характеристикою [Собчик, 2000].

А. Баканова у своїй роботі «Екзистенційний контекст подолання кризових ситуацій в зрілому віці» зазначає, що в цілому подолання стресу має у чоловіків і жінок загальні закономірності, можливо, обумовлені культурно і соціально, які проявляються у використанні копінг-стратегій когнітивної сфери, що говорить про тенденції раціонально усвідомлювати ситуацію, яка склалася. Цікаво, що жінки більшою мірою, ніж чоловіки, використовують такі стратегії, як «релігійність», «емоційне розвантаження» і «покірність / безнадійність». У поведінці ж чоловіків частіше зустрічаються стратегії «самоспостереження», «надання сенсу» $\mathrm{i}$ «придушення емоцій». Чоловіки і жінки відчувають найбільші труднощі у використанні ефективних копінг-стратегій емоційної сфери, оскільки стратегії на кшталт «придушення емоцій», «самозвинувачення» або «безнадійність» найбільш деструктивно позначаються на психологічному здоров'ї особистості. Жінки емоційніше реагують на кризові ситуації та суб'єктивно вище оцінюють силу своїх переживань, частіше вдаються до зовнішньої допомоги для їх розв’язання і довше сприймають ситуації як остаточно невирішені. Чоловіки, навпаки, у кризі намагаються контролювати свої емоції, спиратися у вирішенні проблеми на власні ресурси і більш рішуче справлятися 3 труднощами, які виникли, та не залишають їх на майбутнє [Баканова, 2000].

В іншій своїй роботі А. Баканова зазначає, що специфічною особливістю дівчат є глибоке емоційне проживання кризової ситуації i вміння побачити в ній сенс. Останні, стикаючись 3 кризою, заглиблюються в iii переживання і осмислення, в результаті чого стають здатними звертатися до екзистенційних аспектів важких життєвих обставин, наділяти їх особливим змістом. Специфічною особливістю юнаків $\epsilon$ прагнення знижувати емоційну значущість кризової ситуації за рахунок відходу від іiі глибокого усвідомлення. Юнаки губляться, стикаючись 3 
кризою, виявляються занадто захопленими негативними переживаннями, що зрештою змушує їх втікати від усвідомлення своїх переживань [Баканова, 2002].

$€$. Чехлатий у своїх дослідженнях зазначає, що в розподілі бажаних копінг-стратегій поведінки у чоловіків і жінок з невротичними розладами $\epsilon$ багато спільного. Разом з тим, чоловіки надають значно більшу перевагу стратегіям «планування розв'язання проблем», аніж «пошуку соціальної підтримки», в той час як жінки навпаки. Чоловіки більш схильні використовувати стратегію «позитивна переоцінка», ніж «втечауникнення», натомість у жінок встановлені зворотні співвідношення. Також були виявлені гендерні відмінності в стилях адаптації: жінки більш гнучко використовують стратегії подолання в різних сферах життя, вдаючись до підтримки соціального оточення, пошуку емоційної підтримки та ін. При використанні стратегії «пошук соціальної підтримки» чоловіки частіше шукають додаткову інформацію, а жінки - емоційну підтримку оточення [Чехлатый, 2007].

I. Seiffge-Krenke (I. Сейфi-Кренке) з'ясувала, що юнаки та дівчата порізному оцінюють одні й ті ж стресові ситуації [Seiffge-Krenke, 1995]. Так, дівчата оцінюють їх як більше загрозливі, ніж юнаки-ровесники. Вони описують одну й ту ж проблему як більш складну. I навіть після того, як ситуація розв'язалася, продовжують думати про неї. Автор стверджує, що незалежно від типу проблеми дівчата частіше говорять про неї зі значущими іншими і зазвичай намагаються вирішити конфлікт 3 тією людиною, з якою він пов'язаний. Юнаки такої активності не демонструють, у ситуацію втягуються не так сильно, намагаються впоратися зі стресом самостійно, легше забувають про проблему.

Американським дослідником Sh. Taylor (Ш. Тейлор) 3 колегами була вивчена інша система реагування, на їхню думку, більш характерна для жінок, яка отримала назву «tend-and-befriend» - «турбота і підтримка, співпраця» [Tailor, 1995]. Дана модель подолання життєвих труднощів полягає в тому, що жінки схильні реагувати на стресову ситуацію, захищаючи себе і своє потомство засобом виховної поведінки (це відноситься до тієї частини системи, яка називається «турбота»), а також шляхом об'єднання в альянси 3 іншими людьми, посилення соціальних контактів, проявів бажання в приєднанні. На відміну від жінок серед чоловіків тенденція турботи і прагнення до співпраці проявляється менше, тому, стверджують дослідники, чоловічий тип реагування доцільно співвідносити з реакцією на стрес у вигляді боротьби або втечі.

C. Aldwin (К. Алдвін) досліджувала особливості подолання стресу у чоловіків і жінок середнього віку в різних ситуаціях (робота і сім'я) [Aldwin, 1982]. Чоловіки, в основному службовці середньої ланки, проявляли хороші навички розв'язання конфліктної ситуації на роботі, покладаючись переважно на побудову стратегій, спрямованих на міркування про проблему. Проте в сімейних ситуаціях вони частіше бували 


\section{Psychology}

некомпетентними та уникали рішення проблем з дітьми. Жінки виявилися більш досвідченими у розв'язанні сімейних проблем, втім лише дехто 3 досліджуваних працювали, головним чином клерками або секретарями. Вони були менш кваліфікованими і більш схильними використовувати емоційно-орієнтовані стратегії в ділових ситуаціях.

У дослідженні гендерної ідентичності молодих дружин і вибором ними стилів поведінки подолання стресу, отримані схожі результати. Проблемно-орієнтований копінг негативно корелює з фемінним типом гендерної ідентичності. Отже, такі жінки у важких життєвих ситуаціях користуються іншими стратегіями подолання стресу. Автором встановлено, що для фемінних жінок більшою мірою характерний емоційно-орієнтований копінг, і особливо копінг, орієнтований на уникнення проблеми, однією зі сторін якого є схильність до пошуку соціальної підтримки. Подолання, орієнтоване на розв'язання проблеми, вважають за краще представники маскулинного і андрогінного типів гендерної ідентичності [Лебедев, 2002].

У дослідженні авторів статті гендерних особливостей копінгповедінки вибірку склали 20 чоловіків і 20 жінок. Віковий розподіл респондентів - 20-25 років.

Для вивчення базових копінг-стратегій була використана методика «Індикатор стратегій подолання стресу» Дж. Амірхана. Використовуючи факторний аналіз, учений ідентифікував три базові копінг-стратегії: «розв'язання проблем», «пошук соціальної підтримки» та «уникання проблем». Переваги даного опитувальника полягають у простоті та зручності використання, а також можливості застосування для діагностики копінгу в осіб підліткового, юнацького віку та дорослих. Дана методика була адаптована Н. Сиротою та В. Ялтонським [Сирота, Ялтонский, 1995].

Результати емпіричного вивчення частоти обрання чоловіками та жінками копінг-стратегій, які були отримані за допомогою опитувальника Дж. Амірхана «Індикатор копінг-стратегій» наведені в табл. 1.

Табличя 1

Результати дослідження частоти обрання чоловіками та жінками копінг-стратегій (у \%)

$\mathrm{n}=40$

\begin{tabular}{|l|c|c|}
\hline \multicolumn{1}{|c|}{ Копінг-стратегії } & Чоловіки & Жінки \\
\hline Розв'язання проблем & 50 & 35 \\
\hline Пошук соціальної підтримки & 30 & 45 \\
\hline Уникання & 20 & 20 \\
\hline
\end{tabular}

Емпіричне вивчення частоти вибору чоловіками та жінками певних копінг-стратегій дозволяє стверджувати, що серед них домінують «розв'язання проблем» та «пошук соціальної підтримки».

Так, копінг-стратегія «розв'язання проблем» виявилася провідною у $50 \%$ чоловіків та $35 \%$ жінок. Це активна поведінкова стратегія, при якій 
людина намагається використовувати всі наявні у неї особистісні ресурси для пошуку можливих способів ефективного вирішення проблеми. Цим досліджуваним притаманний логічний аналіз кризової ситуації, детальне планування дій та раціональні зважені кроки щодо іiі усунення або нейтралізації негативних наслідків, що, у свою чергу, сприяє розширенню репертуару пошуку ними альтернативних варіантів розв'язання проблеми та швидкості у прийнятті рішень. Копінг-стратегію «пошук соціальної підтримки» обрали в якості провідної $30 \%$ чоловіків та 45 \% жінок. У процесі подолання стресу їх характеризує пошук емоційної та інструментальної підтримки у свого найближчого соціального оточення, що сприяє зростанню самооцінки, впевненості у собі та підвищує опір впливу стрес-факторів. Отримані дані, на нашу думку, свідчать про те, що жінки частіше вдаються до емоційно-фокусованого копінгу, звертаються за підтримкою до близьких людей, підсилюють соціальні контакти.

Проте, варто зазначити, що 20 \% чоловіків та 20 \% жінок у процесі подолання стресу обирають копінг-стратегію «уникання». Вони намагаються уникати кризових ситуацій або дистанціюватися від них, спрямовуючи свої психічні ресурси в інше русло, занурюючись у світ власних переживань та звинувачуючи у власних проблемах оточуючих. Ці досліджувані не намагаються, а часто і неспроможні адекватно оцінити кризову ситуацію та власні потенції для іiї подолання.

Висновки дослідження $\boldsymbol{i}$ перспективи. Таким чином, можна сказати, що жінки орієнтовані не стільки на психологічне подолання важкої життєвої ситуації, скільки на пристосування до неї. Їхню поведінку у стані стресу можна охарактеризувати як пасивну, орієнтовану на виживання та пошук соціальної підтримки. Копінг-стратегії чоловіків грунтуються на незалежних та активних діях, емоційній стійкості та самоефективності, що характеризує проблемно-фокусовані стратегії подолання труднощів. До стратегії «розв'язання проблем» частіше вдаються чоловіки, оскільки їм притаманно розв`язувати труднощі інструментально, шляхом зміни зовнішньої ситуації. Також це може бути зумовлено гендерними особливостями виховання в сім ях. Жінкам властиво використовувати копінг-стратегію «пошук соціальної підтримки». Вони не стільки долають важку ситуацію, скільки пристосовуються до неї. Жінки частіше орієнтуються на думку та підтримку інших, мріють про диво, звертаються до релігії. Респондетів, які обрали копінг-стратегію «уникання», була рівна кількість серед чоловіків та жінок. Таким людям притаманно не вирішувати свої проблеми, а уникати їх.

На нашу думку, серед перспектив у даному питанні є подальші дослідження гендерних особливостей копінг-поведінки та розробка програм для ефективного подолання стресу. 


\section{Psychology}

\section{ЛITEPATУРА}

Баканова, 2000 - Баканова А. А. Экзистенциальный аспект преодоления кризисных ситуаций в зрелом возрасте. Санкт-Петербург, 2000. 16 с.

Баканова, 2002 - Баканова А. А. Экзистенциальный аспект преодоления кризисных ситуаций в юношеском возрасте. Безопасность жизнедеятельности - профессия XXI века: проблемы становления и перспективы развития: Сборник трудов Всероссийской научно-практической конференции. Санкт-Петербург, 19-20 ноября 2002 г. СанктПетербург, 2002. С. 82-84.

Лебедев, 2002 - Лебедев И. Б. Психологические механизмы, стратегии и ресурсы стресспреодолевающего поведения (копинг-поведения) специалистов экстремального профиля (на примере МВД России). Автореф. дисс. док. псих. наук. Москва, 2002. 40 с.

Москвитина, 2002 - Москвитина О. А. Гендерные различия в способах совладающего поведения. Проблемы психологии XXI века глазами молодых ученых. Тезисы. Материалы научнопрактической конференции. МГППУ. Москва, 2002. С. 124.

Сирота, Ялтонский, 1995 - Методика «Индикатор копинг-стратегий». Режим доступу: https://studfiles.net/preview/5288138/page:16/

Собчик, 2000 - Собчик Л. Н. Введение в психологию индивидуальности: Теория и практика психодиагностики. 3-е изд. Москва : Ин-т современ. политики, 2000. $511 \mathrm{c.}$

Чехлатый, 2007 - Чехлатый Е.И. Совладающее поведение у больных неврозами, лиц с преневротическими нарушениями и в социальных группах повышенного риска нервнопсихических расстройств: Автореф. дисс. д-ра мед. наук: 19.00.04, 14.00.18; ГУ СПб НИПНИ им. В.М.Бехтерева Росздрава. Санкт-Петербург, 2007. 58 с.

Aldwin, 1982 - Aldwin C. The role of values in stress and coping processes: A study in person situation interactions. Unpublished doctoral dissertation University of California. San Francisco, 1982, $215 \mathrm{p}$.

Amirkhan, 1990 - Amirkhan J. H. A Factor analytically derived measure of coping: The coping strategy indicator. J. Pers. Soc. Psychol. 1990. Vol. 59. № 5. P. 1066-1074.

Lazarus, Folkman, 1987 - Lazarus R. S. and Folkman S. Transactional theory and research on emotions and coping. European journal of personality. 1987. V. 1. P. 115.

Murphy. 1962 - Murphy L. The widening world of childhood. New York : Basic Books, 1962, 138 p.

Seiffge-Krenke, 1995 - Seiffge-Krenke I. Stress, Coping and Relationships in Adolescence. Lawrence Erlbaum Ass. Inc., Publishers, 201 p.

Tailor, 1995 - Taylor Shelley E. Health Psychology. McGraw-Hills, Inc. 1995, 149 p.

\section{REFERENCES}

Bakanova, 2000 - Bakanova A. A. Ekzistentsialnyiy aspekt preodoleniya krizisnyih situatsiy v zrelom vozraste. Sankt-Peterburg, 2000. $16 \mathrm{c}$.

Bakanova, 2002 - Bakanova A. A. Ekzistentsialnyiy aspekt preodoleniya krizisnyih situatsiy v yunosheskom vozraste. Bezopasnost zhiznedeyatelnosti - professiya XXI veka: problemyi stanovleniya i perspektivyi razvitiya: Sbornik trudov Vserossiyskoy nauchno-prakticheskoy konferentsii, Sankt-Peterburg, 19-20 noyabrya 2002 g. Sankt-Peterburg, 2002. S. 82-84

Lebedev, 2002 - Lebedev I. B. Psihologicheskie mehanizmyi, strategii i resursyi stresspreodolevayuschego povedeniya (koping-povedeniya) spetsialistov ekstremalnogo profilya (na primere MVD Rossii). Avtoref. diss. dok. psih. nauk. Moskva, 2002.

Moskvitina, 2002 - Moskvitina O. A. Gendernyie razlichiya v sposobah sovladayuschego povedeniya. Problemyi psihologii XXI veka glazami molodyih uchenyih. Tezisyi. Materialyi nauchnoprakticheskoy konferentsii. MGPPU. Moskva, 2002.

Sirota, Yaltonskiy, 1995 - NII im. V. M. Behtereva. N. A. Sirota, V. M. Yaltonskiy, 1995 god. [Elektronnyi resurs]. Rezhym dostupu: https://studfiles.net/preview/5288138/page:16/

Sobchik, 2000 - Sobchik L. N. Vvedenie v psihologiyu individualnosti : Teoriya i praktika psihodiagnostiki. 3-e izd. Moskva : In-t sovremen. politiki, 2000. 511 s.

Chehlatyiy, 2007 - Chehlatyiy E. I. Sovladayuschee povedenie u bolnyih nevrozami, lits s prenevroticheskimi narusheniyami i v sotsialnyih gruppah povyishennogo riska nervnopsihicheskih rasstroystv: Avtoref. diss. d-ra med. nauk: 19.00.04, 14.00.18. GU SPb NIPNI im. V. M.Behtereva Roszdrava. Sankt-Peterburg, 2007. 58 s. 